\title{
Досвід застосування назального спрею Акварінол з хлоргексидином у пацієнтів у післяопераційний період
}

\author{
О.В. Лисовець, О.В. Сапожніков, І.М. Сапожнікова
}

Медичний центр «Династія», Харків, Україна

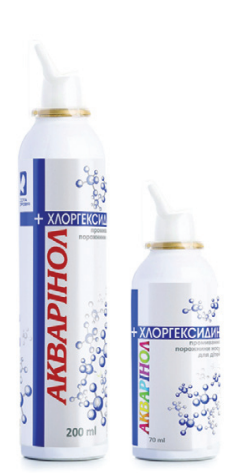

Вільне носове дихання - основа здоров'я всього організму, це аксіома, яка не потребує доказів. Основні операції, що проводяться у клініці Медичного центру «Династія» (Харків), спрямовані на відновлення носового дихання: септопластика, аденотомія, вазотомія, функціональна операція під ендоскопічним контролем (Functional Endoscopic Sinus Surgery FESS), головною метою якої $\epsilon$ відновлення дренування і вентилювання пазух носа через природні сполучення. Запобігання розвитку хірургічних ускладнень - головна складова успіху лікування. Профілактичне застосування антибіотиків з метою запобігання інфекційним ускладненням $\epsilon$ загальновизнаною світовою практикою. Однак доцільність та ефективність цього заходу $є$ фактом суперечливим. Рутинне застосування антибіотиків слід обмежити, їх призначення доцільне лише у разі складних назальних втручань і тривалого застосування інтраназальних тампонів, що передбачає системне застосування антибактеріальних препаратів [1, 2]. Спеціалісти нашого центру приділяють велику увагу правильному веденню хворих у післяопераційний період, оскільки саме на цьому етапі можуть виникати бактеріальні ускладнення, спайковий процес, проблеми 3 відновленням мукоциліарного кліренсу. Тому в нашій практиці дуже важливо застосовувати схеми лікування, які допомагають звести нанівець ризик розвитку ускладнень. Застосування з цією метою антисептиків та дезінфікуючих засобів в пери- та післяопераційний періоди давно знайшло своїх прихильників серед хірургів, зокрема оториноларингологів [2]. Один із таких засобів - хлоргексидин у формі водного чи спиртового розчину - має широкий спектр дії щодо грампозитивних та грамнегативних бактерій, факультативних анаеробів, грибів та деяких вірусів [3, 4].

На базі Медичного центру «Династія» використовували назальний спрей Акварінол з хлоргексидином (ТОВ «Красота та здоров'я», Україна) у дітей віком >6 років та дорослих, яким проведено аденотомію класичним методом/методом кобляції/за допомогою шейвера; FESS; септопластику. Раніше цій категорії пацієнтів після втручання з метою досягнення протизапального та антибактеріального ефекту призначали сольові розчини у формі спрею, після чого - мазь із хлорамфеніколом та метилурацилом. Вибір зумовлений тим, що властивості засобу оптимальні для відновлення пацієнтів у післяопераційний період, а саме він сприяє:

- усуненню закладеності носа і відчуття тиску в носових пазуxax;

- покращенню функції миготливого епітелію, що посилює резистентність слизової оболонки порожнини носа та придаткових пазух до проникання хвороботворних бактерій та вірусів;

- розрідженню слизу та нормалізації його утворення келихоподібними клітинами слизової оболонки носа;

- очищенню слизової оболонки носа від пилу, алергенів та інфікованого назального секрету;

- зменшенню набряку слизової оболонки носової порожнини;

- відновленню прохідності та нормального функціонування дихальних шляхів, пришвидшенню одужання під час захворювань носоглотки і придаткових пазух носа.
Одна з переваг Акварінолу з хлоргексидином - зручність використання та наявність двох форм випуску: для дорослих та дітей, що $є$ особливо корисним, оскільки в нашій хірургічній практиці виконується значна кількість оперативних втручань у дітей. Важливим фактором $\epsilon$ хороша переносимість засобу. Він не викликає блювальних позивів, відчуття печіння та алергічних реакцій. Останнє має особливе значення, оскільки в літературі описані випадки алергічних проявів при застосуванні хлоргексидину [1, 2, 5]. Скорочення часу оброблення слизової оболонки носа порівняно із попередньою схемою лікування $\epsilon$ дуже зручним для паці$\epsilon$ нтів. Інша перевага цього засобу в тому, що до його складу входить антисептик, активний до бактерій та грибів, а не антибіотик. Це дає можливість використовувати Акварінол з хлоргексидином у разі міцетоми придаткових пазух носа. Зазначимо, що кількість звернень із цією патологією останнім часом зростає.

За 6 міс Акварінол з хлоргексидином призначили 231 пацієнтові. Режим використання - 3 рази на добу протягом 10 днів після операції. Показники ефективності та відповідності зазначеним якостям представлені в таблиці. Приводів для скасування/заміни препарату на інший не було.

\begin{tabular}{ccc} 
Таблиця & \multicolumn{2}{c}{ Порівняння властивостей використовуваних засобів } \\
\hline & Акварінол & Сольовий розчин + \\
Властивості & з хлоргекси- & мазь із хлорамфеніколом \\
& дином & та метилурацилом
\end{tabular}

Ефект:

- протизапальний

- протинабряковий

- антибактеріальний

- протигрибковий

$\begin{array}{ll}+ & + \\ + & + \\ + & + \\ + & -\end{array}$

Неприємні відчуття після застосування

(блювальні позиви, гіркий присмак, печіння, кровоточивість слизової оболонки)

\begin{tabular}{lll}
\hline Час, необхідний для проведення процедури, хв & 1 & 5 \\
\hline Кількість процедур на день & 3 & 3 \\
\hline
\end{tabular}

Успішний досвід використання Акварінолу з хлоргексидином свідчить про те, що засіб відповідає всім зазначеним якостям, що дає підставу рекомендувати його пацієнтам вищезазначених категорій у післяопераційний період.

\section{Список використаної літератури/References:}

1. Georgiou I., Farber N., Mendes D. et al. (2008) The role of antibiotics in rhinoplasty and septoplasty: a literature review. Rhinology, 46(4): 267-270.

2. Ricci G., D'Ascanio L. (2012) Antibiotics in septoplasty: evidence or habit? Am. J. Rhinol. Allergy, 26(3): 194-196.

3. Webster J., Osborne S. (2015) Preoperative bathing or showering with skin antiseptics to prevent surgical site infection. Cochrane Database Syst. Rev., 20(2): CD004985. doi: 10.1002/14651858.CD004985.pub5.

4. Richer S.L., Wenig B.L. (2009) The efficacy of preoperative screening and the treatment of methicillin-resistant Staphylococcus aureus in an otolaryngology surgical practice. Otolaryngol. Head Neck Surg., 140(1): 29-32. doi: 10.1016/j.otohns.2008.10.021.

5. Teixeira de Abreu A.P., Ribeiro de Oliveira L.R., Teixeira de Abreu A.F. (2017) Perioperative Anaphylaxis to Chlorhexidine during Surgery and Septoplasty. Case Rep. Otolaryngol., 2017: 9605804. doi: 10.1155/2017/9605804. 